\title{
Social network analysis of local water user associations' actors: evidence from Iran
}

Hamid Basati, Alireza Poursaeid, Mohammad Sadegh Allahyari*, Roya Eshraghi Samani, Hamed Chaharsoqi Amin

Department of Agricultural Extension and Education, Ilam Branch, Islamic Azad University, Iran, e-mail: a.poursaeed@gmail.com

*Department of Agricultural Management, Rasht Branch, Islamic Azad University, Rasht, Iran

\section{DOI: $10.26491 / \mathrm{mhwm} / 116668$}

ABSTRACT. The purpose of this study was to investigate social network analysis (SNA) indicators of actors among exploiters, members of local water user associations (WUA), and their boards of directors in llam Province, Iran. The network analysis method and Ucinet 6 software were used to examine the information exchange network and the network of participation among the members of the WUAs across the province. The actors of the local WUAs in the study area included the Water Supply Organization, the Agri-Bank, the Agricultural and Natural Resources Management Organization, the Agriculture Organization, the Department of Cooperatives, Labor and Social Welfare, the Provincial Government, the Village Council and Rural Municipalities, the Agricultural Insurance Fund, and the Regional Water Company of the province. Among the experts, one was selected from each organization or administration via the purposeful sampling method. A questionnaire containing 20 items with a Likert-type scale was designed for data collection, and the actors active in the field of local WUAs were asked to determine the information exchange rate and the participation of their organization/administration with other organizations/administrations. In addition, the relationship between the active actors and local WUAs was examined from the perspective of the actors in the province. The results of the analysis of the density index at the whole level of the information exchange network and the participation network showed that the density of the links to exchange information and participate in the network of actors was low across the provincial WUAs. In total, according to network density indicators, network size, centrality (concentration) of the entire network, and the social cohesion of the information exchange network and the network of participation were ranked to be weak to moderate.

KEYWORDS: Social network analysis, actors, WUAs, Ilam Province. 


\section{INTRODUCTION}

Water is an important factor in agriculture and plays a decisive role in economic growth and development. Water scarcity is a growing concern in most developing countries, calling for more advanced patterns of water consumption and sound irrigation policies (Hadizadeh et al. 2018; Valizadeh et al. 2019). According to the National Drought and Crisis Management Agency of Iran's Meteorological Organization (2016), Iran has been suffering from mild drought for the last 5 years, and the last wet year of the country occurred at around 2006-2007. Considering that about 70 percent of the global water resources are consumed by agricultural activities, the actors of this economic sector must develop and adopt mechanisms for balanced and optimal water consumption (Aminian 2009). Thus, given the water resource crisis and the management crisis that have been plaguing many of the provinces and watersheds of the country in recent years, participatory management and stakeholder participation in planning and decision making can facilitate and accelerate the achievement of sustainability in water resource management while increasing confidence in success.

Ilam province is currently suffering from a lack of water resources (Regional Water Company of Ilam Province 2016). In addition to severe water scarcity, the enforcement of a subsidy reform, the increase in water and energy costs, and the imminent implementation of fair water distribution, which will not be efficient under the status quo of agricultural water use in the region, will increase production costs and decrease income, thereby further complicating the agricultural problems of the region. A reasonable solution for these problems is the adoption of participatory management of agricultural water use and the improvement of irrigation efficiency (Nejadrezaei et al. 2018). However, to implement water resources management, it is necessary to consider important social components and influential indicators. Social capital is one of the important factors in the relationship among stakeholders, which is investigated on the basis of network analysis methodology prior to the implementation of participatory water resources management and any water-related projects based on the participation of local communities, leading to a deeper understanding of the challenges and opportunities faced by managers and planners. In general, social capital has a positive effect on the interaction of participants in a social network (Kim, Hastak 2018).
Social network analysis (SNA) focuses on the structure of ties within a set of social actors, e.g., persons, groups, organizations, and nations, or the products of human activity or cognition such as web sites, semantic concepts, and so on (Carrington et al. 2005; Tulin et al. 2018). It was developed in the 1930s to investigate the link between local patterns of human relationships and social processes, such as the impact of social groups on the likelihood of being obese (Farine, Whitehead 2015). The aim of social network analysis is to understand a community by mapping the relationships that connect its members as a network and then trying to draw out key individuals, groups within the network ('components'), and/or associations between individuals (Bodin, Crona 2009). This approach will generate diagrams that will show the relationships between individuals, contained in data.

Since the late 1980s, the tendency to transfer water resource management and irrigation networks from the public sector to water user associations (WUAs) has been enhancing increasingly with the use of exploiter participation, as this is the case in many water-scarce countries as the national determination and politics (Sajasi et al. 2014). In fact, companies such as local WUAs have been established to operate and maintain water management networks, with the main objective of optimizing water resources management for sustainable development (Mirzai et al. 2011). These companies use human, physical and natural capital in the framework of participatory management for sustainable development. Therefore, WUAs represent the first form of a participatory management approach adopted by the water management sector (Hassabou, El-Gafy 2007).

Various studies have examined WUAs in Iran and other countries, approaching the subject matter from different dimensions. For example, a study conducted by Sabouri et al. (2014) showed that member farmers had higher participation in social activities than non-member farmers, along with a larger network of social relationships, higher social trust, and strong social cohesion, benefitting from further activities and promotional programs. In this regard, Salari et al. (2015) assessed the social capital of the local stakeholder network of water in the customary system of Resin Village with respect to local water management. Their results emphasize the use of the SNA method in local water management, and the authors noted that the use of this method and the measurement of social capital would contribute to improving participatory water management to maintain and develop water resources. This is mainly because poor social capital and the lack of unity among individuals would impair trust and participation, and consequently, good governance would challenge water resources. Ebrahimi et al. (2014) analyzed a social network of stakeholders in the Water Management Action Plan for Water Resources in Jajroud River and concluded that strengthening social cohesion and social capital among local stakeholders was a requirement for the Water Resources Participatory Water Management Action Plan to achieve water sustainability and security. Other researchers, e.g., Facon (2002) and Kadirbeyoglu and Ozertan (2011), mentioned the lack of social capital as a reason for the failure of irrigation management transfer. In this regard, Ababneh and $\mathrm{Al}$ Adwan (2012) and GTZ (2010) report that the lack of a legal framework for the transfer of irrigation management, infrastructure erosion, social factors, and negative experiences with previously implemented participatory projects will result in the failure of irrigation management transfer to farmers. The results of a study by Lienert et al. (2013) on the existing policies for water infrastructure in Switzerland, using SNA, showed that this approach could provide appropriate and good results that could be used to address various problems in stakeholder relationships, affecting decision-making and water policy issues. Similarly, Stein et al. (2011) analyzed the role of social networks and the impact of these networks on good water management practices in a water basin in Tanzania. The result emphasized the application of network analysis as a systematic way of describing the relations between local stakeholders for water governance and considered the presence of local leaders in the villages as one of the main components of this process.

Fliervoet et al. (2016) conducted a social network analysis of floodplain management in the Dutch Rhine Delta and showed the dependence of non-governmental actors on the main governmental organizations. It seems that the Dutch governmental organizations still play a dominant and controlling role in floodplain management, challenging the alleged shift from a dominant government towards collaborative governance and calling for a detailed analysis of actual governance. Chaffin et al. (2016) presented a method for resolving this problem by describing the results of an institutional SNA aimed at characterizing the changing governance network in the Klamath River Basin, USA, during a period of contested nego- 
Table 1. Actors of Local Water User Associations in Ilam Province

\begin{tabular}{|l|l|c|}
\hline Actors & Interviewee & $\begin{array}{c}\text { Abbreviation } \\
\text { of actors }\end{array}$ \\
\hline Water Supply Organization & Co-operative Managing Director & ACO \\
\hline Agri-Bank & Deputy Chief and Supervisor & 60 \\
\hline Agricultural and Natural Resources Management Organization & Head of the organization & 35 \\
\hline Agriculture Organization & Technical deputy & 35 \\
\hline Department of Cooperatives, Labor and Social Welfare & Deputy Director-General of Cooperatives & ANO \\
\hline Provincial Government & Deputy of planning & AO \\
\hline Village Council and Rural Municipalities & Presidency of the Council & 40 \\
\hline Agricultural Insurance Fund & Agricultural insurance expert & 30 \\
\hline Regional Water Company & Expert on llam Regional Water Distribution & COA \\
\hline
\end{tabular}

Table 2. Important indicators in social network analysis (source: Bodin, Crona 2009; Ghorbani et al. 2013; Rezaei et al. 2015)

\begin{tabular}{|l|l|}
\hline Indicators & Description \\
\hline Density & $\begin{array}{l}\text { The ratio of all available ties to all possible ties. Therefore, the density is referred to as the number of ties associated with a node and, in other words, nodes that are related } \\
\text { to the considered node. }\end{array}$ \\
\hline Centrality & The strength of a node based on the amount of relation on the network. Centrality can be discussed regarding the location of the node, the type of tie, and the relation. \\
\hline In-degree centrality & The number of nodes that an actor receives. A high in-degree reflects a person's reputation or authority. \\
\hline $\begin{array}{l}\text { Out-degree cen- } \\
\text { trality }\end{array}$ & The number of nodes leaving an actor. The high out-degree indicates the influence of the actor, which is further discussed in the data transmission network. \\
\hline Reciprocity & This indicator plays a role in determining the sustainability of the network and is obtained by examining the interaction between actors. \\
\hline Transitivity & $\begin{array}{l}\text { This indicator comes from sharing ties between three individuals, one of which is the bridge between the two other people. As the number of people transporting ties is } \\
\text { higher, this rate is higher, and as a result, relationships sustain among actors. }\end{array}$ \\
\hline Network size & The number of ties in a network of relations. As the number of ties increases, the density will increase in the network of relations. \\
\hline
\end{tabular}

tiations over water. The results showed that employing this type of SNA is useful for describing potential and actual transitions in governance that yield increases in adaptive capacity to respond to social and biophysical surprises such as increasing water scarcity and changes in water distribution.

Ogada et al. (2017) used stakeholder analysis and social network analysis to analyze stakeholders' social and structural characteristics based on their interests, influence, and interactions regarding the Lake Naivasha basin, Kenya. Interactions in the basin are guided by stakeholders' interest and sphere of influence, which have both promoted participation in implementing a collaborative water governance framework.

According to a previous study, the establishment of local WUAs has accelerated the development of water distribution networks, and exploiters have been encouraged to participate financially and to exploit water management systems (Heydarian 2003). On the other hand, researchers have considered the increased social cohesion, development of social participation, and, most importantly, the mutual trust of individuals as the necessary conditions for the development of any society (e.g., Bhagavatula et al. 2010). Trust is the main factor of development and one of the most important components of social capital. There is a significant relationship between the level of trust and the development of societies, and therefore, developed societies have higher levels of trust than other societies (Fukuyama 2001). In fact, trust is a precondition for participation and cooperation, and the survival and sustainability of the relations between actors depend on the trust of individuals. Also, trust can play an important role in resolving disputes and conflicts among exploiters in the process of water resource management (Bodin, Prell 2011). The results of various studies show that the use of social network analysis is effective in local water governance and measuring social capital can improve participatory water management in order to conserve and develop water resources. Because the weakness of social capital and the lack of unity and unity among individuals will lead to a loss of trust and participation, this will challenge the adequate governance of water resources. Therefore, the purpose of the present study was to investigate the indicators of social network analysis of actors among exploiters, members of local WUAs, and their boards of directors in Ilam Province.

\section{METHODOLOGY \\ 2.1. STUDY AREA}

Ilam Province, one of the 31 provinces of Iran, is located in the western part of the country, bordering Iraq. In 2014, it was placed in Region 4. Covering an area of 19,086 square kilometers (about $4.1 \%$ of Iran), Ilam Province shares its borders with three neighboring Iranian provinces and Iraq: Khuzestan Province in the south, Lurestan Province in the east, Kermanshah Province in the north, and Iraq in the west, with 425 kilometers of common border. The population of the province is approximately 600,000 people (2015 estimate). The counties of Ilam
Province are Eyvan County, Chardavol County, Sirvan County, Ilam County, Malekshahi County, Mehran County, Badreh County, Darreh Shahr County, Abdanan County, and Dehloran County. The northern region of Ilam, due to its high elevation, experiences cold winters and mild summers and receives the highest amount of precipitation in the province. The variety of land is one of the main reasons for the prevalence of nomads in the area (Aliakbari et al. 2015).

\subsection{SAMPLES \\ AND DATA COLLECTION}

A survey study was designed for data collection. The statistical population of the study was composed of the actors of the local Ilam WUAs, including the Water Supply Organization, the Agri-Bank, the Agricultural and Natural Resources Management Organization, the Agriculture Organization, the Department of Cooperatives, Labor and Social Welfare, the Provincial Government, the Village Council and Rural Municipalities, the Agricultural Insurance Fund, and the Regional Water Company of the province. During data collection in 2018, one person from each organization or administration was selected as a contact person (Table 1).

\subsection{DATA ANALYSIS}

We used a quantitative research approach in terms of paradigm; the survey was applied and descriptive. The network analysis method and the Ucinet6 software were used to examine the information exchange net- 
Table 3. Review of the information exchange network and the participation network in the current situation among actors from their point of view

\begin{tabular}{|c|c|c|c|c|c|}
\hline \multirow{2}{*}{ Actors } & \multirow{2}{*}{ View of the actors } & \multicolumn{4}{|c|}{ Items } \\
\hline & & No relation & Low & High & Very high \\
\hline \multirow{2}{*}{ Regional Water Company } & Views of actors about the information exchange network (people) & 29 & 83 & 253 & 0 \\
\hline & Views of actors about the participation network (people) & 20 & 229 & 116 & 0 \\
\hline \multirow{2}{*}{ Agricultural Insurance Fund } & Views of actors about the information exchange network (people) & 48 & 330 & 14 & 0 \\
\hline & Views of actors about the participation network (people) & 45 & 302 & 18 & 0 \\
\hline \multirow{2}{*}{ Water Supply Cooperative } & Views of actors about the information exchange network (people) & 19 & 45 & 301 & 0 \\
\hline & Views of actors about the participation network (people) & 3 & 114 & 248 & 0 \\
\hline \multirow{2}{*}{ Agri-Bank } & Views of actors about the information exchange network (people) & 20 & 327 & 18 & 0 \\
\hline & Views of actors about the participation network (people) & 52 & 289 & 24 & 0 \\
\hline \multirow{2}{*}{ Agricultural and Natural Resources Engineering Organization } & Views of actors about the information exchange network (people) & 200 & 155 & 10 & 0 \\
\hline & Views of actors about the participation network (people) & 207 & 156 & 2 & 0 \\
\hline \multirow{2}{*}{ Village Council and Rural Municipalities } & Views of actors about the information exchange network (people) & 30 & 324 & 11 & 0 \\
\hline & Views of actors about the participation network (people) & 268 & 66 & 31 & 0 \\
\hline \multirow{2}{*}{ Department of Cooperatives, Labor and Social Welfare } & Views of actors about the information exchange network (people) & 92 & 263 & 10 & 0 \\
\hline & Views of actors about the participation network (people) & 92 & 263 & 10 & 0 \\
\hline \multirow{2}{*}{ Agriculture Organization } & Views of actors about the information exchange network (people) & 83 & 194 & 88 & 0 \\
\hline & Views of actors about the participation network (people) & 183 & 120 & 62 & 0 \\
\hline \multirow{2}{*}{ Provincial Government } & Views of actors about the information exchange network (people) & 344 & 20 & 1 & 0 \\
\hline & Views of actors about the participation network (people) & 344 & 20 & 1 & 0 \\
\hline
\end{tabular}

Table 4. Indicators of network analysis of actors of local water user associations

\begin{tabular}{|c|c|c|c|c|c|c|c|c|c|}
\hline Link type & 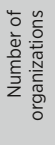 & 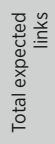 & 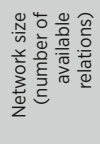 & $\begin{array}{l}\frac{\delta}{\vdots} \\
\frac{1}{4} \\
\frac{5}{0} \\
0\end{array}$ & 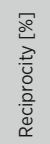 & 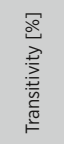 & 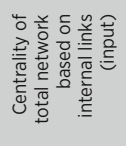 & 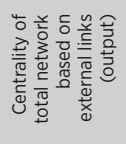 & 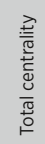 \\
\hline Information exchange & 9 & 420 & 299 & 36.7 & 55.5 & 32.35 & 15.65 & 26.73 & 36.7 \\
\hline Participation & 9 & 420 & 296 & 36.5 & 55.5 & 32.47 & 13.16 & 29.78 & 36.5 \\
\hline
\end{tabular}

work and the network of participation among the members of WUAs across the province. This software is one of the most widely used social network analysis software packages to draw up social networks and create and display multiple relations in these networks. It uses a set of nodes representing the variables of the research and a series of ties between nodes to show the relations and drawings within the social network. The social network can quantitate the qualitative data using mathematics, and thus, the differences are generally represented in the form of a series of indicators, enabling comparisons and analysis (Alizadeh, Siddiqi 2013). In the study of the existing status of actors in the local Ilam WUAs, a questionnaire composed of 20 items with a Likerttype scale (no relationship to very strong relationship) was designed, and the active actors in the field of provincial WUAs (Table 1) were asked to express the amount of information exchange and the participation rate of their organization/administration with other organizations/administrations during 1 year. In addition, the relationship between active actors with respect to the local WUA in the province was examined from the perspective of actors.
There are many indicators to analyze social networks. One of the main indicators is centrality, according to which the in-degree centrality is the degree of reputation and authority of each actor and the out-degree centrality indicates the social or political influence of the actor. Also, indicators such as density, reciprocity, transitivity, and network size are among the indicators used in this study (Table 2). The values for each index are calculated from 100; values below 50 indicate a weak index, and values above 50 indicate a strong index.

\section{RESULTS \\ 3.1. INFORMATION EXCHANGE NETWORK \\ AND PARTICIPATION \\ NETWORK AMONG \\ ACTORS OF LOCAL WUAS}

To examine the information exchange network and the actor participation network, actors were asked to determine the extent of their work relationship with other actors in the province on a Likert scale. The actors of the local WUAs in the province of Ilam include the Water Supply Organization, the Agri-Bank, the Agricultural and Natural Resources Management Organization, the Agriculture Organization, the Depart- ment of Cooperatives, Labor and Social Welfare, the Provincial Government, the Village Council and Rural municipalities, the Agricultural Insurance Fund, and the Regional Water Company of the province. One expert was selected from each organization or administration. In total, according to Table 3, Water Supply Cooperatives and Regional Water Companies of the province were the main and most important actors from the perspective of local WUAs, and the Agricultural and Natural Resources Engineering Organization and the Provincial Government were the two actors that most organizations were unrelated to.

\subsection{RELATIONSHIP OF ACTORS ON THE ACTIVITIES OF LOCAL WUAS WITHIN INFORMATION EXCHANGE NETWORKS AND PARTICIPATION NETWORKS}

The structural analysis of the social network of actors of local WUAs at the provincial level was studied in the form of an information exchange network and a participation network. The indicators examined for SNA are presented in Table 4. 


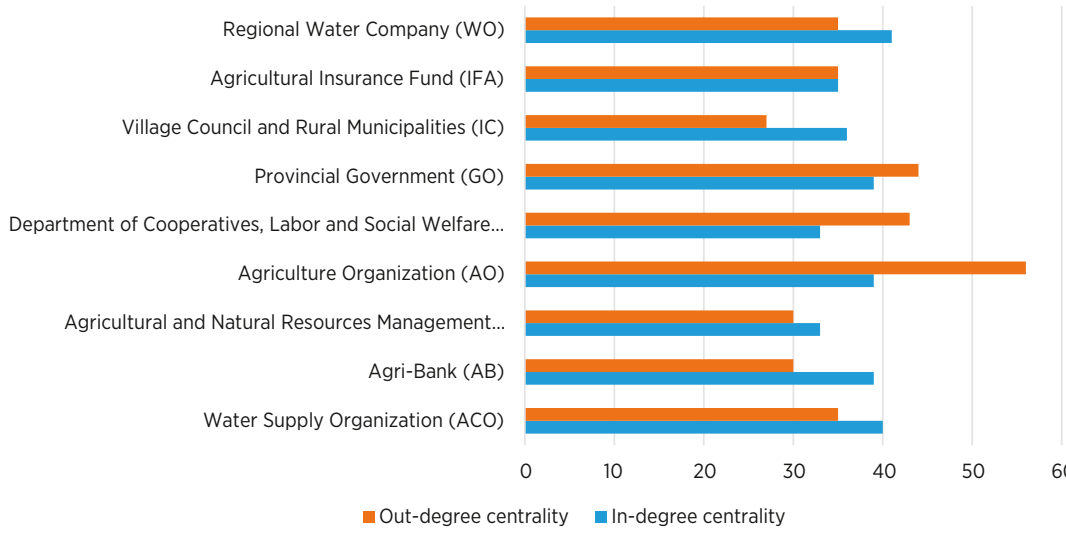

Fig. 1. In- and out-degree centrality in the information exchange network of actors of the local WUAs

\subsection{INFORMATION EXCHANGE NETWORK FROM THE PERSPECTIVE OF LOCAL WUA ACTORS}

The result of the analysis of the density index at the total level of the information exchange network shows that the size of this index was 36.7 percent at the total level of information exchange links (Table 4). This value indicates the low density of information exchange links in the network of actors in the local WUAs in the province. Since the density is directly related to social cohesion, the level of social cohesion was also weak.

According to the results, the size of the network shows 299 connections from all expected links ( 420 cases), that is, more than half of the expected links have been formed. As the size of the network increases, the density of the network also increases. Thus, based on the size of the network, the density and social cohesion are at a moderate level. Another indicator focused on to study social cohesion is the centrality (centration) of the entire network based on internal and external links. According to the results (Table 4), the focus of the network has increased more on the basis of external links than on the internal links in the information exchange network. This means that it was not affiliated with central actors based on internal links or network information reception; receiving information is not in their monopoly, and more people are effective in information reception. However, according to external links, the dispersion of information is monopolized by limited and fewer individuals. In total, according to the indicators of the network density, network size, centrality (concentration) of the entire network, and the social cohesion of the information exchange network are weak to moderate.
Given that the reciprocity index of links expresses the mutuality of the relationships in the network, it can be stated that network sustainability has a direct relationship with the reciprocity rate of links. According to the results, the reciprocity of links in the information exchange network of actors of local WUAs was 55.5 percent. Therefore, based on this indicator, it can be said that the sustainability of the information exchange network is moderate. In addition to the reciprocity index, the index of transitivity of the links also indicates the sustainability of the network in that the value of this index was 32.35 percent according to the results of the study, indicating that sustainability is weak in the information exchange network. In general, according to the two indicators of reciprocity and transitivity of links, network sustainability is weak to moderate. To investigate the role of different organizations in the information exchange network, the values of the in- and out-degree centrality were compared (Fig. 1).

The in-degree centrality is the number of nodes that an actor receives. A high in-degree reflects the reputation or authority of an actor. According to Figure 1, the Regional Water Company, with the highest in-degree centrality (41), followed by the Water Supply Cooperatives, with an in-degree centrality of (40), had the highest authority and reputation and are therefore the most trusted actors in the information exchange network of local WUAs of the province. However, the actors believed that the Department of Cooperatives, Labor and Social Welfare, and the Provincial Government had the lowest position among actors in terms of information in-degree, and this finding does not seem desirable.

A high out-degree centrality also reflects the influence of an actor. Thus, as evident in Figure 1, the Agriculture Organization of the province is considered the main actor in social influence and has the most public relationships with other actors in the field of information exchange. The Provincial Government and the Department of Cooperatives, Labor and Social Welfare are at the next ranks of social influence. The Islamic Council and Rural Municipalities are ranked the last in social influence in terms of information exchange. Although Water Supply Companies and the Regional Water Company have good centrality in information exchange and are highly trusted and authority actors, they are in a lower position in terms of out-degree centrality and social influence (out-degree centrality of 35).

\subsection{PARTICIPATION NETWORK FROM THE PERSPECTIVE OF LOCAL WUA ACTORS}

The low density value of 36.5 percent in the links of the participation network of actors of local WUAs represents social cohesion and, consequently, poor social capital in the participation network of actors of local WUAs. According to the results of the study, the participation network size is 296 links of the 420 expected links, suggesting that more than half of the expected links have been formed in the participation network. Based on the network size index, the density and subsequent social cohesion of the network are moderate. To investigate social cohesion, the index of total centrality (total concentration) was also examined; based on the results (Table 4), the concentration of the network has increased on the basis of external links to the internal links in the participation network. This means that according to the internal links of the network, it has not been dependent on the central actors and their activity monopoly, and more people are effective in receiving participation. However, based on external links, the dispersion of participation and participatory activities occurs by fewer individuals. In comparison with the information exchange network, dispersion of participation is made in the form of a more compact structure because the centrality of the participation network is more based on the external links than the information exchange network. In general, according to the network density indicators, network size and total network centrality (concentration), actor participation network, social cohesion, and social capital are weak to moderate.

Based on the results presented in Table 4, the reciprocity of the links in the participa- 
tion network (interactions) of the local WUAs was 55.5 percent, indicating the sustainability of the participation network. Also, the value of the transitivity index of 32.47 percent represents the poor sustainability of the participation network of local WUA actors. Therefore, considering the reciprocity and the transitivity of the links, network sustainability is weak to moderate.

To examine the role of various organizations in the participation network of local WUAs, the in- and out-degree centralities were calculated (Fig. 2).

According to Figure 2, the Agriculture Organization of Ilam Province had the highest in-degree centrality (46), followed by the Regional Water Company (41) and the Water Supply Cooperative (40) with the highest reputation and power among the actors of the local WUAs, considered the most trusted actors in the field of participation. This indicates the awareness of other actors about the role of these two sets in the field of local WUAs in the province. However, according to the actors, the Islamic Council and the Agricultural Engineering Organization have the lowest position in participation in terms of authority and reputation, and there is a need to strengthen their position. The high out-degree of centrality represents the actor's influence. According to Figure 2, the Department of Cooperatives, Labor and Social Welfare, he Agriculture Organization, the Provincial Government, the Regional Water Company, and the Water Supply Cooperative with the highest out-degree centrality values (47, 44, 42, and 35) are the most influential actors, while the Insurance Fund has the lowest level in terms of social participation in the partnership network. According to Figure 2, the Islamic Council and the Rural Municipalities not only have a weak position in terms of authority and reputation, but they also require further attention and improvement in relation to social influence (their in- and out-degree centralities were 30 and 29, respectively).

The QAP indicator is used in the Ucinet software to examine the correlation between the links of the information exchange network and the partnership network. Based on this indicator, the correlation between two networks of information exchange and participation has a high coefficient value (correlation coefficient $=$ 0.95), and the significance level of the correlation between these two networks is zero. This value expresses the significance of the correlation between the two links of information exchange and participation at the significance level of 1 percent.

Regional Water Company (WO)
Agricultural Insurance Fund (IFA)

Village Council and Rural Municipalities (IC)

Provincial Government (GO)

Department of Cooperatives, Labor and Social Welfare...

Agriculture Organization (AO)

Agricultural and Natural Resources Management...

Agri-Bank (AB)

Water Supply Organization (ACO)
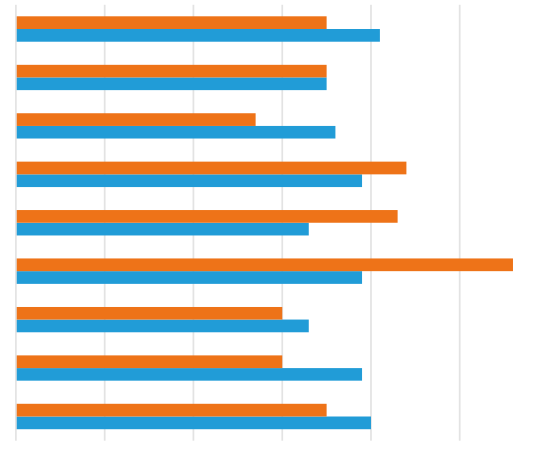

10

20

60

- Out-degree centrality $\quad$ In-degree centrality

Fig. 2. In- and out-degree centrality in the participation network of local WUAs

Accordingly, if there is a link between the two actors of the local WUAs, there is a participation link between the two actors of the local WUAs with the probability of 1 percent. Thus, the information exchange network serves as a starting point and the foundation or facilitating factor for the participation network.

\section{DISCUSSION \\ AND CONCLUSION}

As previously stated, social network analysis is a new approach to planning for participatory water resources management. By studying social networks using network analysis techniques, researchers can identify challenges to participatory processes in the management of water resources (Bodin, Crona 2009). The results of this study show that Water Supply Companies and the Regional Water Company of the province are the main and most important actors from the viewpoint of the actors of local WUAs, while the Agricultural and Natural Resources Engineering Organization and the Provincial Government are two actors that most organizations are unrelated to. Therefore, the strengthening of relationships with these organizations is necessary, and measures should be taken to facilitate the relationship with these organizations, such as the reduction of the administrative bureaucracy process.

The results of the analysis of the density index at the whole level of the information exchange network show that the density in the links of information exchange in the network of actors of local WUAs in the province is low. Taken together, according to the network density indicators, the network size, the centrality (concentration) of the entire network, and the social cohesion of the information exchange network are at a weak to moderate level. These results are consistent with the results obtained by Taghipour et al. (2015) and Sabouri et al. (2014). Therefore, participatory management in local WUAs is challenging, and efforts to increase the density of these associations are essential.

Based on the results, the Regional Water Company, with the highest in-degree centrality, and the Water Supply Cooperative have the first and second highest authority and reputation, respectively, and are the most trusted actors in the information exchange network of local WUAs in the province. However, according to the views of the actors, the Department of Cooperatives, Labor and Social Welfare and the Provincial Government have the lowest position among the actors in terms of information input degree, and this finding does not seem desirable. According to the results, the Agriculture Organization, the Regional Water Company, and local WUAs are the most trusted actors and enjoy greater influence. Therefore, these organizations can be used to encourage exploiters and actors to participate with each other and to strengthen the role of other organizations in the network of relations between actors.

The transitivity rate of the links also reflects the poor sustainability of the participation network of local WUAs; therefore, considering the reciprocity and transitivity of the links, network sustainability is weak to moderate. The Agriculture Organization in the province of Ilam, with the highest in-degree centrality, and the Regional Water Company and Water Supply Cooperative have the highest reputation and authority among the actors of the provincial WUAs and are therefore considered the most trusted actors in the field of participation. This indicates the high awareness and familiarity of other actors with the role of the two sets in the field of local WUAs in the province. According to the actors, the Islamic Council 
and the Agricultural Engineering Organization have the lowest position in participation in terms of authority and reputation and are therefore advised to improve their position. In addition, the Department of Cooperatives, Labor and Social Welfare, the Agriculture Organization, the Provincial Government, the Regional Water Company, and the Water Supply Cooperative exhibit the highest out-degree centrality and are the most influential actors. However, the Insurance Fund showed the lowest level in terms of social participation in the partnership network. According to the results, the Islamic Council and the Rural Municipalities not only have no good position in terms of authority and reputation, but they also need to improve their position with respect to social influence. Based on the results, to improve the social cohesion and participation of the exploiters of the local WUAs, several training courses are proposed to familiarize people with WUAs and their limitations. Quantity orientation is also prohibited in the establishment of cooperatives, and few WUAs should be established, but consciously and with awareness of the people. It is suggested to create and strengthen social capital in the villages by associations through the expression of the importance of collective actions in the form of associations and co-operatives and the common interests of these activities through radio, television programs, and visiting successful associations.

\section{REFERENCES}

- Ababneh Z., Al Adwan A., 2012, Water users association in the Jordan Valley, Sustainable Water Integrated Management (SWIM)

- Aliakbari M., Gheitasi M., Anonby E., 2015, On language distribution in llam Province, Iran, Iranian Studies, 48 (6), 835-850, DOI: 10.1080/00210862.2014.913423

- Alizadeh N., Seddiqi H., 2013, Processing and analyzing data in a sociometric method using Ucinet6 software, First edition, University Jahad Publishing (Tehran Branch)

- Aminian F., 2009, Investigating the economic value of agricultural water (case study: Damghan groundwater resources), Master's Thesis, Tabriz University, Iran

- Asadpour H., Ahmadi G., Taslimi M., 2009, Investigation of the performance of water user association in the country in recent years, Sixth Iranian Agriculture Economics Conference, Islamic Azad University, Dezful Branch, Iran

- Bhagavatula S., Elfring T., Tilburg A., Gerhard G., Bunt V., 2010, How social and human cap- ital influence opportunity recognition and resource mobilization in India's hand loom industry, Journal of Business Venturing, 25 (3), 245-260, DOI: 10.1016/j.jbusvent.2008.10.006

- Bodin Ö., Crona B.I., 2009, The role of social networks in natural resource governance: What relational patterns make a difference?, Global Environmental Change, 19 (3), 366-374, DOI: 10.1016/j.gloenvcha.2009.05.002

- Bodin O., Prell C., 2011, Social network in natural resources management, Cambridge University Press, $390 \mathrm{pp}$.

- Carrington P.J., Scott J., Wasserman S., 2005, Models and methods in social network analysis, Cambridge University Press, New York, $328 \mathrm{pp}$.

- Chaffin B.C., Garmestani A.S., Gosnell H., Craig R.K., 2016, Institutional networks and adaptive water governance in the Klamath River Basin, USA, Environmental Science \& Policy, 57, 112121, DOI: 10.1016/j.envsci.2015.11.008

- Ebrahimi F., Ghorbani M., Salajeghah A., Mohseni Saravi M., 2014, Analysis of local social network of local beneficiaries in action research of water resources management (case study: Jajroud Basin, Darbandsar Village), Iranian Journal of Engineering and Watershed Management, 8 (25), 47-56

- Facon T., 2002, Downstream of irrigation water pricing - the infrastructure design and operational management considerations, paper presented at the conference: Irrigation Water Policies: Micro and Macro Considerations, Agadir, Morocco, 15-17 June 2002

- Farine D.R., Whitehead H., 2015, Constructing, conducting and interpreting animal social network analysis, Journal of Animal Ecology, 84 (5), 1144-1163, DOI: 10.1111/1365-2656.12418

- Fliervoet J.M., Geerling G.W., Mostert E., Smits A.J.M., 2016, Analyzing collaborative governance through social network analysis: a case study of river management along the Waal River in the Netherlands, Environmental Management, 57 (2), 355-367, DOI: 10.1007/ s00267-015-0606-x

- Fukuyama F., 2001, Social capital, civil society and development, Third World Quarterly, 22 (1), 7-20

- Ghorbani M., Azarnivand H., Mehrabi A.A., Bastaani S., Jafari M., Nayebi H., 2013, Social network analysis; A new approach in policy making and planning of participatory management of natural resources, Journal of Range and Watershed Management, 65 (4), 553-568

- GTZ, 2010, Water User Associations (WUA): The story of participative irrigation management in the Jordan Valley. Amman: GTZ
- Hadizadeh F., Allahyari M.S., Damalas C.A., Yazdani M.R., 2018, Integrated management of agricultural water resources among paddy farmers in northern Iran, Agricultural Water Management, 200, 19-26, DOI: 10.1016/j.agwat.2017.12.031

- Hassabou A.H.M., El-Gafy I.K., 2007, Assessment indicators for Water Users' Associations in Egypt, E-WAter, Official Publication of the European Water Association (EWA), available online at http://www.ewa-online.eu/ tl_files/_media/content/documents_pdf/Publications/E-WAter/documents/26_2007_02. pdf (data access 17.01.2020)

- Heydarian S.A., 2003, Management transfer: methods, barriers and Solutions, [in:] The third technical workshop on water supply participation in managing irrigation networks, 25-80

- Kadibeyoglu Z., Ozertan G., 2011, Users' perceptions of Water User Associations: evidence from three cases in Turkey, Working Papers, 1 , $29 \mathrm{pp}$.

- Kazbekov J., Abdullaev I., Manthrithilake H., Qureshi A., Jumaboev K., 2009, Evaluating planning and delivery performance of Water User Associations (WUAs) in Osh Province, Kyrgyzstan, Agricultural Water Management, 96 (8), 1259-1267, DOI: 10.1016/j.agwat.2009.04.002

- Kim J., Hastak M., 2018, Social network analysis: characteristics of online social networks after a disaster, International Journal of Information Management, 38 (1), 86-96, DOI: 10.1016/j.ijinfomgt.2017.08.003

- Lienert J., Schnetzer F., Ingold K., 2013, Stakeholder analysis combined with social network analysis provides fine-grained insights into water infrastructure planning processes, Journal of Environmental Management, 125, 134148, DOI: 10.1016/j.jenvman.2013.03.052

- Mirzai A., Mirdamadi S.M., Hosseini S.M., 2011, Water supply cooperatives: a new approach to collaborative irrigation management, Journal of Agricultural Engineering and Natural Resources Engineering, 7 (27), 18-22

- Najafi N., Khosravi P.B., Ghanian M., Baradaraan M., Dahmavi A., 2013., Identifying the barriers to the success of water supply associations in the view of the exploiters of the North and South Karkheh Areas of Khuzestan Province, Rural Research, 4 (1), 165-188

- Nejadrezaei N., Allahyari M.S., Sadeghzadeh M., Michailidis A., El Bilali H., 2018, Factors affecting adoption of pressurized irrigation technology among olive farmers in Northern Iran, Applied Water Science, 8 (6), DOI: 10.1007/s13201-018-0819-2 
- Ogada J.O., Krhoda G.O., Veen A.V., Marani M., Van Oel P.R., 2017, Managing resources through stakeholder networks: collaborative water governance for Lake Naivasha basin, Kenya, Journal Water International, 42 (3), 271-290, DIO: 10.1080/02508060.2017.1292076

- Pant N., 2008, Key issues in Participatory irrigation management, [in:] Managing water in the face of growing scarcity, inequality and declining returns: exploring fresh approaches, M.D. Kumar (ed.), Proceedings of the 7th annual Partner Meet, IWMI TATA Water Policy Research Program, ICRISAT, 2-4 April 2008 Patancheru, Hyderabad, India, Vol. 2, 541-557

- Qiao G., Zhao L., Klein K.K., 2009, Water user associations in Inner Mongolia: factors that influence farmers to join, Agricultural Water Management, 9 (5), 822-830, DOI: 10.1016/j.agwat.2008.11.001

- Rezaie A., Hosseini S.M., Asadi A., 2015, Analysis of the information exchange network in the direction of sustainable management of natural resources (study area: Alborz dam basin in Mazandaran Province), Journal of Range and Watershed Management, Iranian Journal of Natural Resources, 68 (1), 65-80

- Sabouri F., Rezaei M.K., Mantizadeh M., 2014, Investigating the status of social capital among member and non-member farmers of agricultural associations: case study of Garmsar farmers, Cooperatives and Agriculture, 3 (11), 95-117

- Sajasi K.H., Mahdavi F.G.R., Rajabi J.D.S., 2014, Prioritizing the establishment of Water User Association in rural areas (case study: Villages of Salami Village in Khaf County), Journal of Rural Development Strategies, 1 (1), 57-69

- Salari F., Ghorbani M., Malekian A., 2015, An analysis of the local social networking of local beneficiaries for local water management (case study: Resin Basin in Kermanshah), Journal of Range and Watershed Management, 68 (2), 287-305
- Stein C., Ernstson H., Barron J., 2011, A social network approach to analyzing water governance: the case of the Mkindo catchment, Tanzania, Physics and Chemistry of the Earth, 36 (14-15), 1085-1092, DOI: 10.1016/j.pce.2011.07.083

- Taghipour M., Abbasi E., Chizari M., Heidari A.G., 2015, Attitudes of farmers in Gachsaran county to the formation of water supply cooperatives, Cooperatives and Agriculture, 2 (6)

- Tulin M., Pollet T.V., Lehmann-Willenbrock N., 2018, Perceived group cohesion versus actual social structure: a study using social network analysis of egocentric Facebook networks, Social Science Research, 74, 161-175, DOI: 10.1016/j.ssresearch.2018.04.004

- Valizadeh N., Bijani M., Hayati D., 2019, A comparative analysis of behavioral theories towards farmers' water conservation, International Journal of Agricultural Management and Development, 9 (1), DOI: 10.22004/ ag.econ. 292562 